\title{
Correlation Between Personal Integrity and Leadership Among Medical Students
}

\author{
Putu Asih Primatanti ${ }^{1 *}$, Artha Budi Susila Duarsa ${ }^{2}$, Irwan Syuhada ${ }^{2}$ \\ ${ }^{1)}$ Faculty of Medicine and Health Sciences, University of Warmadewa, Bali \\ ${ }^{2)}$ Faculty of Medicine, Al-Azhar Islamic University \\ *Corresponding author. Email: dr.putuasihprimatanti@gmail.com
}

\begin{abstract}
A medical student is hoped to be a leader for himself and to another health professional in the future. Integrity will boost the quality of honesty and strong moral values among leaders. This study aimed to examine the correlation between personal integrity and leadership among medical students. A cross-sectional study was conducted at Al-Azhar Islamic University, Mataram, West Nusa Tenggara. A total of 241 were selected to participate in this study. The dependent variable was leadership and the independent variable was personal integrity. The data were obtained from the Minnesota Multiphasic Personality Inventory-2 (MMPI-2) test. The data were analyzed using the Chi-square test. Among 241 medical students at Al-Azhar Islamic University, Mataram, West Nusa Tenggara, 182 (75.52\%) students had good leadership and 195 (80.91\%) had good integrity. After the data from MMPI-2 were analyzed using Chi-square, it was found that leadership significantly correlated with integrity $(\mathrm{p}=0.010)$. Leadership is correlated with integrity among medical students at Al-Azhar Islamic University. Medical students should improve their leadership so it can contribute positively to the person, faculty, and wider community.
\end{abstract}

Keywords: integrity, leadership, MMPI-2.

\section{INTRODUCTION}

A medical student is hoped to be a leader for himself and to another health professional in the future. As a prospective doctor, medical students must acquire different competencies specified in the Indonesian Doctor Competency Requirements. It is because a doctor will become a pioneer and a leader in the health sector, which is supposed to bring improvement both in the health sector itself and in the field of medicine in Indonesia [1].

Leadership course intended to establish medical students as responsive leaders, teammates, and advocates for medically underserved communities. In a study by Warde et al. after completion of the leadership course, students possessed qualities that define effective and trustworthy physician leaders; they were more mindful, related to each other effectively, and coordinated their activities well with one another [2]

Besides leadership, integrity is an important thing that must have by medical student. It is not only needed when they become doctors, but it is also needed when they are studying at a medical education institution. With the existence of integrity in each medical student, the level of honesty and morale as a prospective professional leader and doctor will also be better.

Integrity can be defined as the resistance and persistence of an individual in maintaining good values. A person with high integrity will always prioritize the needs of others and maintain the obligations assigned to him. Integrity is also related to honesty and other moral values to produce good performance or achievement. Besides, integrity is also a combination of various universal positive traits [3].

Doctors will seek to promote and protect patients' interests above and beyond their own interests. The ethical concept of fiduciary professionalism, expressed in part by the professional virtue of integrity, is defined by these norms. Integrity is the bedrock virtue, and in accordance with the standards of moral and intellectual excellence, it is defined by a commitment to practice medicine [4].

In Indonesian society, integrity is often associated with leadership in a person. A leader who has high integrity is often associated with a leader who has high moral standards, honesty, and good leadership. Based on this background, researchers are interested in researching the relationship between integrity and leadership in 
medical students at the Faculty of Medicine, Al-Azhar Islamic University, Mataram.

\section{SUBJECTS AND METHOD \\ 2.1 Study Design}

A cross-sectional study was carried out at the Faculty of Medicine, Al-Azhar Islamic University, Mataram, West Nusa Tenggara, Indonesia, from June to August 2020.

\subsection{Population and Sample}

The population in this study were all medical students at the Faculty of Medicine, Al-Azhar Islamic University, Mataram, West Nusa Tenggara, Indonesia. A number of 241 students are chosen for this study.

\subsection{Study Variables}

The dependent variable examined in this study was leadership and the dependent variable was integrity among medical students in the Faculty of Medicine, AlAzhar Islamic University.

\subsection{Data Analysis}

The data were obtained from the bioethics field from the Faculty of Medicine, Al-Azhar Islamic University medical students were obtained from the academic bioethics field. The data of leadership and integrity among medical students were obtained from the MMPI2 test. The valid data were included in this study, while the invalid data were excluded.

\subsection{Research Ethic}

The Ethic committee of the Faculty of Medicine, AlAzhar Islamic University allowed this research. The research ethic of this study was presented with the number of 026/EC/FK-06/UNIZAR/VIII/2020.

\section{ReSUltS}

Table 1 shows the data about leadership and integrity among the medical students in the Faculty of Medicine, Al-Azhar Islamic University. Total of 199 students had good leadership (82.57\%), and 42 students had moderate leadership (17.43\%). Total of 213 students had good integrity $(88.38 \%)$, and 28 students had moderate integrity $(11.62 \%)$.

Table 1. Characteristics of Research Subjects on Leadership and Integrity

\begin{tabular}{|c|c|c|c|}
\hline No & Characteristics & $\mathbf{n}$ & Percentage \\
\hline \multicolumn{4}{|c|}{ Leadership } \\
\hline 1. & Good & 199 & 82.57 \\
\hline 2. & Moderate & 42 & 17.43 \\
\hline \multicolumn{4}{|c|}{ Integrity } \\
\hline 1. & Good & 213 & 88.38 \\
\hline 2. & Moderate & 28 & 11.62 \\
\hline
\end{tabular}

The Table 2, showed the result of Chi-square bivariate analysis of leadership and integrity among medical students. The table showed that a total of 179 medical students $(74.3 \%)$ had good leadership and good integrity. Total of 20 medical students $(8.3 \%)$ had good leadership and moderate integrity. Total of 34 medical students $(14.1 \%)$ had less leadership and good integrity. Total of 8 medical students $(3.32 \%)$ had less leadership and less integrity. Bivariate analysis of this data showed that there was a relationship between motivation and integrity among medical students, and it was statistically significant (0.001).

Table 2. Chi-square bivariate analysis of leadership and integrity among students.

\begin{tabular}{|c|c|c|c|c|c|c|c|}
\hline \multirow{3}{*}{ Variable } & \multicolumn{4}{|c|}{ Integrity } & \multirow{2}{*}{\multicolumn{2}{|c|}{ Total }} & \multirow{3}{*}{$\mathbf{p}$} \\
\hline & \multicolumn{2}{|c|}{ Good } & \multicolumn{2}{|c|}{ Less } & & & \\
\hline & $\mathbf{N}$ & $\%$ & $\mathbf{N}$ & $\%$ & $\mathbf{N}$ & $\%$ & \\
\hline $\begin{array}{l}\text { Leadership } \\
\text { Good }\end{array}$ & 179 & 74.3 & 20 & 8.3 & 241 & 100 & 0.001 \\
\hline Moderate & 34 & 14.1 & 8 & 3.32 & & & \\
\hline
\end{tabular}

\section{DISCUSSION}

In this study, the leadership and integrity among medical students were measured from data obtained through the 2nd edition of the Minnesota Multiphasic Personality Inventory (MMPI-2) test. The MMPI-2 test is a development of the MMPI test that has existed since 
1943. The MMPI-2 test has been translated into various languages, one of which is Indonesian. The MMPI test is also one of the most widely used and standardized personality tests worldwide [5].

In the MMPI-2 the test outcome was usually derived from the form including a simple personality index, as well as findings and recommendations filled out by the psychiatrist in charge of the test. In addition, in the MMPI-2 test, conclusions can be drawn about the psychological potential of students which consists of various items, two of which were items of leadership and integrity.

From the analysis of leadership and integrity items on the MMPI-2 test among medical students of the Faculty of Medicine, Al-Azhar Islamic University, it was found that most of the students had good leadership and integrity, with a percentage of $75.52 \%$ and $80.91 \%$ respectively. The results of the analysis of this item also show that there is a relationship between good leadership and integrity among medical students of the Faculty of Medicine, Al-Azhar Islamic University.

In this study, it was found that there was a relationship between integrity and leadership among medical students of the Faculty of Medicine, Al-Azhar Islamic University. These results are following the perceptions that exist in a society that a good leader is known as a leader who has integrity.

A competent doctor not only has good academic and clinical qualifications but also has good leadership. Strong leadership in a doctor is required when the doctor later goes into society and collaborates with other health professionals. Having a leadership for a doctor cannot be ruled out because the medical profession is a noble profession that aims not only to cure the ill but also to keep a healthy society from getting sick. So that with strong leadership skills, a doctor can lead himself and other professionals in the health sector in order to make improvements in the health sector.

Not only leadership, medical students as a future doctor, but must also have integrity. Integrity means consistency between words and acts [6]. Integrity can also be interpreted as a person's resistance to the temptation to commit actions that are contrary to prevailing ethical and moral values [3].

Integrity is not only required when students are already involved in the world of work but must have been nurtured when a student carries out his studies at a university. Student integrity is also correlated with acts that are against the rules on campus, such as never lying to lecturers about absences, not cheating by cheating or copying and stealing ideas and ideas from others, and not doing gratitude [7]. After becoming a doctor, integrity is needed, especially when faced with a situation that requires ethical decisions related to his patients [8].

\section{CONCLUSION}

Leadership and integrity were found to be correlated among medical students of the Faculty of Medicine, AlAzhar Islamic University. Leadership and integrity among medical students were two aspects that were crucial for students as future doctors not only in study process but also in society.

\section{AUTHORS' CONTRIBUTIONS}

In the design and implementation of the study, analysis of the results, and writing of the manuscript, Putu Asih Primatanti, Artha Budi Susila Duarsa, and Irwan Syuhada contribute equally.

\section{ACKNOWLEDGMENTS}

All the authors expressed their gratitude to the Faculty of Medicine, Al-Azhar Islamic University, for permitting and supporting this study.

\section{REFERENCES}

[1] KKI. Standar Kompetensi Kedokteran Indonesia. Jakarta: Konsil Kedokteran Indonesia; 2012.

[2] Warde CM, Vermillion M, Uijtdehaage S. A medical student leadership course led to teamwork, advocacy, and mindfulness. Fam Med 2014;46:459-62.

[3] Gea AA. Integritas Personal dan Kepemimpinan Etis. Humaniora 2014;5:950. https://doi.org/10.21512/humaniora.v5i2.3197.

[4] Coverdale JH, Roberts LW, Balon R, Beresin E V., Louie AK, Guerrero APS, et al. Professional integrity and the role of medical students in professional self-regulation. Acad Psychiatry 2016;40:525-9. https://doi.org/10.1007/s40596016-0534-y.

[5] Friedman AF, Bolinskey PK, Levak RW, Nichols DS. Psychological Assessment with the MMPI-2/MMPI-2-RF. 3rd (Third. New York: Routledge; 2015.

[6] Palanski ME, Yammarino FJ. Integrity and leadership: A multi-level conceptual framework. Leadersh Q 2009;20:405-20. https://doi.org/10.1016/j.leaqua.2009.03.008.

[7] Redjeki DPS, Herdiansyah J. Memahami Sebuah Konsep Integritas. J Pelopor Pendidik STIE Semarang 2013;5:1-14.

[8] Wisesa A. Integritas moral dalam konteks pengambilan keputusan etis. J Manag Teknol 2011;10:82-92. 